\title{
Variable strength of top-down effects in Nothofagus forests: bird predation and insect herbivory during an ENSO event
}

\author{
C. NOEMI MAZIA, ${ }^{1 \star}$ ENRIQUE J. CHANETON, ${ }^{2}$ THOMAS KITZBERGER ${ }^{3}$ AND \\ LUCAS A. GARIBALDI ${ }^{3,4}$ \\ ${ }^{1}$ Cátedra de Dasonomía, Facultad de Agronomía, ${ }^{2}$ IFEVA-CONICET and Facultad de Agronomía, \\ Universidad de Buenos Aires, Av. San Martín 4453, 1417 Buenos Aires, Argentina (Email: \\ cmazia@agro.uba.ar); ${ }^{3}$ Laboratorio Ecotono-CONICET, Universidad Nacional del Comahue, Quintral \\ 1250, Bariloche 8400, and ${ }^{4}$ Cátedra de Métodos Cuantitativos Aplicados, Facultad de Agronomía, \\ Universidad de Buenos Aires, Buenos Aires, Argentina
}

\begin{abstract}
Predators are thought to play a key role in controlling herbivory, thus having positive indirect effects on plants. However, evidence for terrestrial trophic cascades is still fragmentary, perhaps due to variation in top-down forces created by environmental heterogeneity. We examined the magnitude of predation effects on foliar damage by chewing insects and mean leaf size, by excluding birds from saplings in 'dry' and 'wet' Nothofagus pumilio forests in the northern Patagonian Andes, Argentina. The experiment lasted 2 years encompassing a severe drought during the La Niña phase of a strong El Niño/Southern Oscillation event, which was followed by unusually high background folivory levels. Insect damage was consistently higher in wet than in dry forest saplings. In the drought year (1999), bird exclusion increased folivory rates in both forests but did not affect tree leaf size. In the ensuing season (2000), leaf damage was generally twice as high as in the drought year. As a result, bird exclusion not only increased the extent of folivory but also significantly decreased sapling leaf size. The latter effect was stronger in the wet forest, suggesting compensation of leaf area loss by dry forest saplings. Overall, the magnitude of predator indirect effects depended on the response variable measured. Insectivorous birds were more effective at reducing folivory than at facilitating leaf area growth. Our results indicate that bird-initiated trophic cascades protect $N$. pumilio saplings from insect damage even during years with above-normal herbivory, and also support the view that large-scale climatic events influence the strength of trophic cascades.
\end{abstract}

Key words: climate change, drought, folivory, indirect interactions, temperate forest, trophic cascade.

\section{INTRODUCTION}

Large-scale climatic phenomena might alter plantherbivore dynamics from the 'bottom up' by changing abiotic resource levels, and from the 'top down' by modifying trophic interaction strengths (Jaksic 2001; Schmitz et al. 2003). Carnivores are thought to play a key role in controlling herbivory, thereby having positive indirect effects on plants (Hairston et al. 1960; Rosenzweig 1973; Pace et al. 1999). However, the nature and prevalence of such trophic cascades in terrestrial systems is still debated (Schmitz et al. 2000; Halaj \& Wise 2001). It has been suggested that topdown effects from predators and herbivores should be weakened by spatio-temporal heterogeneity in abiotic conditions (Hunter \& Price 1992; Polis 1999). In this context, little attention has been paid to shifts in strength of top-down forces influenced by extreme

${ }^{\star}$ Corresponding author.

Accepted for publication May 2008. climatic events, except for studies on coastal/island communities (Polis et al. 1997; Meserve et al. 2003; Preisser \& Strong 2004; Spiller \& Schoener 2008). Thus, new evidence from a wider array of terrestrial ecosystems is needed to understand the dynamics of trophic cascades in changing environments.

A growing number of studies show that predators might trigger cascades of indirect effects involving herbivorous insects and their food plants (e.g. Marquis \& Whelan 1994; Stiling and Rossi 1997; Fraser and Grime 1998; Van Bael et al. 2003; Letourneau et al. 2004; Mooney 2007). Experimental manipulations of predator abundance have generally yielded smaller effects on plants than on herbivores (Schmitz et al. 2000; Halaj \& Wise 2001; Shurin et al. 2002). The strength of predator indirect effects also depends on the plant response variable measured; trophic cascades have been more detectable on plant damage rather than growth or biomass (Schmitz et al. 2000; Halaj \& Wise 2001). These patterns indicate that top-down effects might become attenuated as they are transmitted to lower trophic levels (Shurin et al. 2002; Gruner 
2004). Both herbivore densities (Strong et al. 2000; Sinclair \& Krebs 2002) and the extent of herbivore impact on plants would be crucial in determining the strength of trophic cascades (Shurin et al. 2002). Low endemic levels of herbivory, coupled with plant compensatory growth or induced defenses, might preclude propagation of top-down effects to plants in land communities (Polis 1999). Yet, how predator indirect effects might be augmented or dampened by largescale climatic anomalies is still poorly understood.

Food-web theory suggests that trophic cascades should be most apparent in highly productive environments (Oksanen et al. 1981; Leibold 1989). Indeed, several studies on insect herbivore-plant interactions have shown that abiotic factors and natural enemies often interact in controlling the amount of herbivory (Hacker \& Bertness 1995; Chase 1996; Stiling \& Rossi 1997; Forkner \& Hunter 2000). This finding led to the notion that bottom-up factors set the stage where topdown forces come into play (Hunter \& Price 1992). Moreover, both predators and their insect prey can be affected by complex environmental patterns involving inter-annual climatic changes superimposed on spatial resource gradients (Ritchie 2000; Mazía et al. 2004). Year-to-year climatic variation might not only impinge directly on plant growth, but might also influence insect abundance and predator activity, thus changing the nature of tritrophic interactions (Mattson \& Haack 1987; Ritchie 2000; Ovadia \& Schmitz 2004; Preisser \& Strong 2004). Recently, Spiller \& Schoener (2008) proposed the strength of top-down forces should be maximum at intermediate rainfall levels. Extreme rainfall regimes would reduce predators' activity, releasing herbivores from top-down control (Ovadia \& Schmitz 2004; Spiller \& Schoener 2008). In this light, abrupt climatic changes associated with phenomena such as El Niño/Southern Oscillation (ENSO) might provide unique opportunities to assess the prevalence of topdown effects in different habitats (Holmgren et al. 2001; Jaksic 2001).

Leaf-feeding insects are the primary herbivores in forest ecosystems (Schowalter \& Lowman 1999). Tree folivory rates typically show substantial variability in time and space (Mattson \& Haack 1987; Shure et al. 1998; Mazía et al. 2004). Large, episodic increases in insect defoliators have been connected with unusually warm and dry periods (Mattson \& Haack 1987; Rouault et al. 2006), and reduced control by natural enemies (Turchin et al. 1999; Dwyer et al. 2004). Foliage-gleaning birds are major predators of forest arthropods (Holmes et al. 1979; Murakami \& Nakano 2000; Gruner 2004). Insectivorous birds have been reported to reduce leaf damage on trees (Marquis \& Whelan 1994; Sipura 1999; Murakami \& Nakano 2000; Strong et al. 2000; Van Bael et al. 2003), although such effects are not universal (Forkner \& Hunter 2000; Low \& Connor 2003). There is less evidence that top-down control of insect folivory actually enhances tree growth parameters (Marquis \& Whelan 1994; Sipura 1999; Mooney 2007; cf. Strong et al. 2000; Gruner 2004). Bird predation intensity varies in response to changes in forest productivity and prey abundance (Dwyer et al. 2004; Seagle \& Sturtevant 2005), and might be also influenced by large-scale abiotic fluctuations (Jones et al. 2003).

In this study, we evaluated the magnitude of top-down effects from insectivorous birds in Nothofagus pumilio (lenga) forests of northern Patagonia, Argentina. Our objectives were (i) to quantify the effects of excluding birds on leaf-chewer herbivory and leaf size on tree saplings; (ii) to determine how the strength of predator indirect effects depends on the response variable measured; and (iii) to examine the potential for bird-initiated trophic cascades in 'dry' and 'wet' forest sites, during and after an extreme drought event. We compared bird exclusion effects on leaf damage and mean leaf size of $N$. pumilio saplings for 2 years differing in climate conditions and background folivory levels. The study area was affected by an unusually severe drought in 1998-2000 (Suárez et al. 2004), accompanied by a marked rise in leafchewer damage. Thus, to place our experimental results in a broader context, we looked at baseline data on insect folivory rates (1998-2007) available for the study forests.

\section{METHODS}

\section{Study system}

The study was conducted in monospecific stands of $N$. pumilio (Poepp. et Endl.) Krasser located at $40-41^{\circ} \mathrm{S}$ latitude within Nahuel Huapi National Park, northern Patagonia, Argentina. The climate is cold-temperate, with wet winters and mild but dry summers. Precipitation falls as rain and snow mostly during autumn and winter (April-August) before the main growing season (October-March). The region is characterized by a steep precipitation gradient created by the rain shadow of the Andes. Total annual precipitation declines from $>3000 \mathrm{~mm}$ near the continental divide in the west to $\sim 800 \mathrm{~mm}$ on the eastern foothills of the Andes (Barros et al. 1983). This rainfall pattern is paralleled by a $30 \%$ eastward decrease in aboveground primary productivity (as shown by remote sensing data, see Mazía et al. 2004). Forest soils are poorly developed Andisols derived from volcanic ashes. Nothofagus pumilio dominates native forests above $1000 \mathrm{~m}$ altitude throughout the region (Veblen et al. 1996).

Nothofagus pumilio is a fixed free-growing deciduous species (Kozlowski et al. 1991), which goes through 
more than one period of leaf expansion during the growing season. Both growing conditions in the previous year as well as climate and biotic factors during the current growing season might influence foliage growth patterns. Previous year conditions set the number of pre-formed buds, whereas conditions for the current year determine the realized number and size of expanded leaves (Kozlowski et al. 1991). In northern Patagonia, N. pumilio budbreak occurs during October in the eastern dry forests but is delayed to November in the wettest forests on the west; leaf fall takes place in May.

The experiment was carried out from December to March, during the 1998-1999 and 1999-2000 growing seasons. The average growing season precipitation for the last 20 years (1987-2006) was $203 \pm 120 \mathrm{~mm}$ (mean $\pm \mathrm{SD}$, Bariloche Airport station). Total precipitation in the growing season before the experiment (1997-1998) was $165 \mathrm{~mm}$. During the first study season (1998-1999), the region experienced an extremely severe drought associated with the La Niña phase of a strong ENSO event (Veblen \& Kitzberger 2002). Growing season precipitation was only $9 \%(20 \mathrm{~mm})$ of the long-term average, whereas mean monthly temperatures were $\sim 2^{\circ} \mathrm{C}$ above average. This year was the driest on record since 1905, with drought conditions leading to widespread tree mortality in mixed Nothofagus forests (Suárez et al. 2004). During the second season (1999-2000), rainfall levels were higher $(119 \mathrm{~mm}$ ) but remained $42 \%$ below normal, with mean temperatures $1^{\circ} \mathrm{C}$ above average.

\section{Bird exclusion experiment}

Two forest stands representative of 'dry' and 'wet' $N$. pumilio forests were selected for study. The dry forest site was located at Cerro Challhuaco, $15 \mathrm{~km}$ south of Bariloche $\left(41^{\circ} 12^{\prime} \mathrm{S}, 71^{\circ} 12^{\prime} \mathrm{W} ; \sim 1000 \mathrm{~mm} /\right.$ year $)$, whereas the wet forest site was located at Paso Puyehue, near the border between Chile and Argentina, $45 \mathrm{~km}$ west of Villa La Angostura (40 $37^{\prime} \mathrm{S}$, $71^{\circ} 50^{\prime} \mathrm{W}$; $\left.3000 \mathrm{~mm} / \mathrm{year}\right)$. In December 1998, shortly after leaf expansion, we haphazardly selected $20 N$. pumilio saplings scattered across 2 ha of forest within each study site. Minimum distance between saplings was $5 \mathrm{~m}$. Saplings were $1-1.5 \mathrm{~m}$ tall and $2-3 \mathrm{~cm}$ in basal stem diameter. Half of the trees were caged to exclude birds, whereas the other half were left uncaged as controls. Exclusion cages $(2 \mathrm{~m}$ height $\times 1 \mathrm{~m}$ diameter) were made of chicken-wire netting, with a mesh size of $2.5 \mathrm{~cm}$, and were secured using three, $2.2 \mathrm{~m}$-tall iron rods. The mesh size was adequate to effectively exclude the most common foliage-gleaning birds in the system, the thorn-tailed rayadito (Aphrastura spinicauda) and the white-crested elaenia (Elaenia albiceps), which are $\sim 15 \mathrm{~cm}$ in body length, and are both widely distributed across Andean forests (Deferrari et al. 2001; González-Gómez et al. 2006). Other predators (spiders, parasitoids) could move freely in/out the cages. These cages reduced light levels by less than $5 \%$ and had no measurable effect on air temperatures (saplings were established under relatively closed-canopy conditions with little direct solar radiation). Cages were large enough to avoid physical interference on tree growth for the duration of the study. We decided not to use open-side cages as controls because any artificial structure placed on saplings might still deter foliage-gleaning birds.

In late March 1999 and 2000, we randomly collected 30 mature leaves from the central crown volume of each sapling. In the laboratory, percent leaf area damage was assessed by measuring the area of intact and damaged or missing tissue with a $1-\mathrm{mm}^{2}$ clear plastic grid. The number of damaged leaves was used to estimate damage frequency per tree. Leaf damage was attributed to different feeding guilds following Mazía et al. (2004). Here, we focus on damage caused by leaf-chewing insects, which are particularly vulnerable to being preyed on by birds (Holmes et al. 1979; Sipura 1999; Van Bael et al. 2003). Most chewer damage in $N$. pumilio is produced by lepidopteran caterpillars in the Geometridae and Saturniidae (Gentili \& Gentili 1988; McQuillan 1993; Bauerle et al. 1997). Monthly records for tagged adult trees show that leaf-chewer damage builds up through the growing season, levelling-off by late March (Mazía et al. unpub. data 2006). Although tree leaves are rarely consumed in full, our late-season sampling might underestimate total folivory as insect damage often induces early leaf abscission (Schowalter \& Lowman 1999). With this caveat in mind, damage levels represented cumulative folivory for each study season, and reflected both insect abundance and consumption rates (Shure et al. 1998).

The amount of leaf area remaining in each sample was used to assess the actual (mean) leaf size after birds were excluded from or allowed access to trees. The occurrence of lower damage levels and larger leaf areas in control relative to caged saplings would be consistent with a 'species trophic cascade' (sensu Polis 1999; e.g. see Marquis \& Whelan 1994). Lack of change in mean leaf size in the presence of greater damage would indicate that plants somehow compensated for the leaf area lost to insects, by producing new leaves or by continued expansion of damaged leaves.

Statistical differences in damage frequency, leaf area damage and mean leaf size per tree were determined separately for each study year using two-way ANOvA, with forest site and cage treatment as fixed effects ( $n=10$ saplings). Percent damage data were arcsine square-root transformed to homogenize variances (Levene's test, $P>0.05$ ). We compared the magnitude of bird exclusion effects on insect herbivory and mean 
leaf size within forests by calculating two complimentary 'effect size' indices (Osenberg et al. 1997; Laska \& Wootton 1998). First, to measure the relative importance of bird predation in the context of other relevant factors (i.e. habitat type), we calculated eta-square $\left(\eta^{2}\right)$ for each response variable after ANOvA, where $\eta^{2}=\mathrm{SS}_{\text {effect }} / \mathrm{SS}_{\text {total }}$, the ratio of the between-groups sum of squares and the total sum of squares (Petraitis 1998). Second, to obtain an independent estimate of the magnitude of predation, we used log response ratios $L=\ln \left(X_{\mathrm{E}} / X_{\mathrm{C}}\right)$, where $X_{\mathrm{E}}$ and $X_{\mathrm{C}}$ are the mean values for the exclosure and control treatments, respectively, obtained within a given experiment (Hedges et al. 1999).

\section{Baseline data on insect folivory}

Field experiments can be better interpreted when placed in the context of longer-term baseline data for the processes of interest (Bernardo 1998; Petraitis 1998). Given the unusual climatic conditions prevailing during the study years, we used a 7-year record of leaf damage by chewing insects in dry and wet $N$. pumilio forests to evaluate how insect damage on experimental trees compared against background levels of herbivory observed in 'normal' years. The data series comprised both experimental years (1999 and 2000), spanning from March 1998 to April 2007. In late summer (March-April) of 1998-2000 and 20042007, we quantified the percentage leaf area damaged by insects on permanently marked adult trees within two stands of dry forest and two stands of wet forest ( $n=10$ trees/stand). A full description of these sites is given in Mazía et al. (2004). Herbivory by different feeding guilds was measured as described above for a sample of 30 leaves/tree. Patterns in baseline folivory were examined through generalized linear modelling in STATISTICA for Windows (StatSoft Inc. 1999), using normal errors and the identity link function (Crawley 1993). A maximum-likelihood approach was preferred to deal with unequal sample sizes as not all stands were sampled each year. The forest type and sample year were included as main factors. Data were arcsine square-root transformed before analysis.

\section{RESULTS}

Both the frequency of leaf damage and leaf area damaged by chewing insects were higher in wet than in dry forest saplings throughout the experiment (Tables 1,2). Bird exclusion increased folivory levels in both forest sites (Table 2), and there were no statistically significant site $\times$ cage interactions $(P>0.10)$. The relative impact of bird predation on insect damage differed between study years, as shown by the effect size $\left(\eta^{2}\right)$ of the cage treatment in ANova (Table 2). On average, excluding birds increased the extent of leaf area damage by $63 \%$ and $139 \%$, in 1999 and 2000, respectively (Table 1). Furthermore, in 2000, the frequency of damaged leaves was significantly greater in caged than in control saplings (Tables 1,2). As a result, during the post-drought year, bird access to saplings became a stronger determinant of folivory rates, as compared with forest type.

In 2000, the enhanced effect of bird predation on sapling damage paralleled an overall increase in background folivory (Fig. 1). Baseline data showed that average damage levels on adult $N$. pumilio trees ranged $\sim 0.2-7 \%$. Leaf damage varied markedly among years $\left(\chi^{2}=78.9\right.$, d.f. $\left.=6, P<0.0001\right)$, a pattern chiefly reflecting the elevated folivory experienced by wet forest trees in 2000 (site $\times$ year: $\chi^{2}=23.5$, d.f. $=6$, $P<0.001$, Fig. 1). Thus, leaf damage was generally, but not always, higher in wet than in dry forest sites $\left(\chi^{2}=22.4\right.$, d.f. $=1, P<0.0001$, scaled deviance $=239$, residual d.f. $=225$ ). Folivory levels on experimental saplings fell within \pm 2 SE of the mean recorded for adult trees in 1999-2000 (Fig. 1).

After accounting for the leaf area lost to insects, the average leaf size did not differ between dry and wet

Table 1. Leaf damage frequency, leaf area damaged by chewing insects, and mean leaf size for Nothofagus pumilio saplings in dry and wet forest sites

\begin{tabular}{|c|c|c|c|c|c|}
\hline \multirow[b]{2}{*}{ Variable } & \multirow[b]{2}{*}{ Year } & \multicolumn{2}{|c|}{ Dry forest } & \multicolumn{2}{|c|}{ Wet forest } \\
\hline & & Control $^{\dagger}$ & Cage & Control & Cage \\
\hline \multirow{2}{*}{ Damage frequency $(\%)$} & 1999 & $29.7 \pm 7.3$ & $37.0 \pm 8.9$ & $43.7 \pm 9.2$ & $47.3 \pm 11.5$ \\
\hline & 2000 & $25.0 \pm 7.5$ & $40.7 \pm 9.5$ & $42.7 \pm 8.2$ & $59.3 \pm 9.4$ \\
\hline \multirow[t]{2}{*}{ Foliar damage $(\%)$} & 1999 & $1.47 \pm 0.31$ & $2.26 \pm 0.40$ & $2.18 \pm 0.22$ & $3.73 \pm 0.70$ \\
\hline & 2000 & $1.76 \pm 0.22$ & $4.73 \pm 0.72$ & $3.90 \pm 0.47$ & $8.15 \pm 0.53$ \\
\hline \multirow[t]{2}{*}{ Leaf size $\left(\mathrm{cm}^{2}\right)$} & 1999 & $3.80 \pm 0.15$ & $3.27 \pm 0.18$ & $3.95 \pm 0.21$ & $3.83 \pm 0.28$ \\
\hline & 2000 & $2.74 \pm 0.23$ & $2.56 \pm 0.27$ & $3.15 \pm 0.24$ & $2.30 \pm 0.12$ \\
\hline
\end{tabular}

†Trees were exposed to (control) or protected from (cage) bird access. Values are means \pm SE $(n=10)$. Treatments were initiated after leaf flushing in December 1998; sampling took place in March 1999 and 2000. 
Table 2. Two-way ANova for the effects of bird exclusion on leaf damage frequency, leaf area damaged by chewing insects, and mean leaf size for Nothofagus pumilio saplings in dry and wet forest sites

\begin{tabular}{|c|c|c|c|c|c|c|c|c|c|}
\hline \multirow[b]{2}{*}{ Source } & \multicolumn{3}{|c|}{ Frequency (\%) } & \multicolumn{3}{|c|}{ Foliar damage (\%) } & \multicolumn{3}{|c|}{ Leaf size $\left(\mathrm{cm}^{2}\right)$} \\
\hline & $F$ & $P$ & $\eta^{2}$ & $F$ & $P$ & $\eta^{2}$ & $F$ & $P$ & $\eta^{2}$ \\
\hline \multicolumn{10}{|l|}{1999} \\
\hline Site & 8.53 & 0.006 & 0.184 & 7.17 & 0.011 & 0.143 & 2.92 & 0.096 & 0.069 \\
\hline Cage & 1.74 & 0.195 & 0.038 & 6.92 & 0.013 & 0.138 & 2.40 & 0.130 & 0.057 \\
\hline Site $\times$ Cage & 0.19 & 0.663 & 0.004 & 0.17 & 0.680 & 0.003 & 0.93 & 0.342 & 0.022 \\
\hline \multicolumn{10}{|l|}{2000} \\
\hline Site & 22.03 & 0.0001 & 0.292 & 30.55 & 0.0001 & 0.262 & 0.12 & 0.730 & 0.003 \\
\hline Cage & 17.45 & 0.0002 & 0.231 & 49.70 & 0.0001 & 0.427 & 5.54 & 0.024 & 0.126 \\
\hline Site $\times$ Cage & 0.02 & 0.898 & 0.000 & 0.17 & 0.685 & 0.001 & 2.28 & 0.139 & 0.052 \\
\hline
\end{tabular}

Data were analysed separately for each study year. For all $F$ ratios, d.f. $=1$, 36. Significant effects are shown in bold. $\eta^{2}=\mathrm{SS}_{\text {effect }} / \mathrm{SS}_{\text {total. }}$.

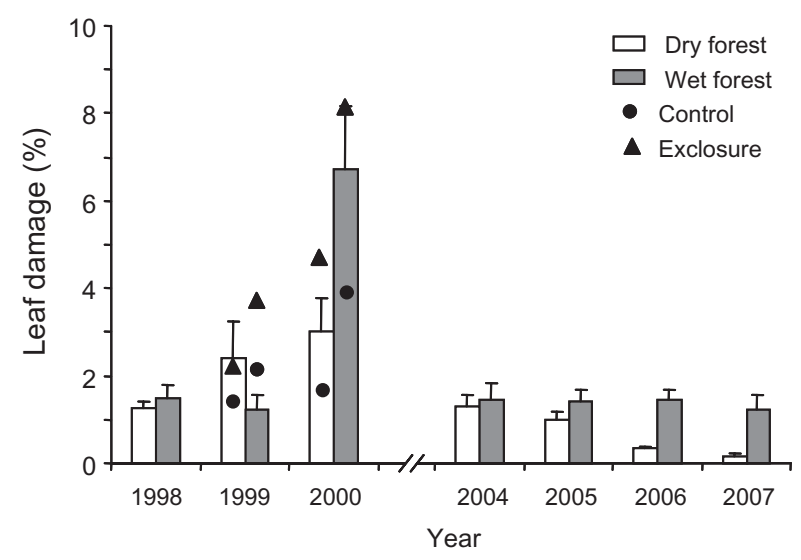

Fig. 1. Baseline pattern of leaf area damaged (\%) by chewing insects in adult Nothofagus pumilio trees from dry and wet forests in northern Patagonia, Argentina. Bars show means +1 SE ( $n=10-20$ trees). Overlay symbols display average damage levels found in control (circles) and caged (triangles) saplings during the bird exclusion experiment.

forest saplings (Tables 1,2). The strength of bird predation effects on mean leaf size depended on the study year. In 1999, bird exclusion did not affect leaf size in either dry or wet forest saplings (Tables 1,2). In 2000, excluding birds significantly decreased sapling leaf size, although the effect magnitude was relatively small (Table 2). Leaves of control trees were, on average, $17 \%$ larger than those of trees without bird access. Although the site $\times$ cage interaction was weak $(P=$ $0.14)$, the exclosure effect on leaf size was significant in the wet forest $\left(t_{18}=3.19, P=0.005\right)$ but not in the dry forest $\left(t_{18}=0.53, P=0.60\right.$; see Table 1$)$. The effect of bird exclusion on leaf area did not involve significant changes in the mean size of undamaged leaves (twoway ANOvA, cage effect: $P=0.44$ ). For both forest sites, the mean leaf size of caged saplings was negatively correlated with the intensity of folivory they experienced (Fig. 2); this relationship did not hold for control saplings (Fig. 2).

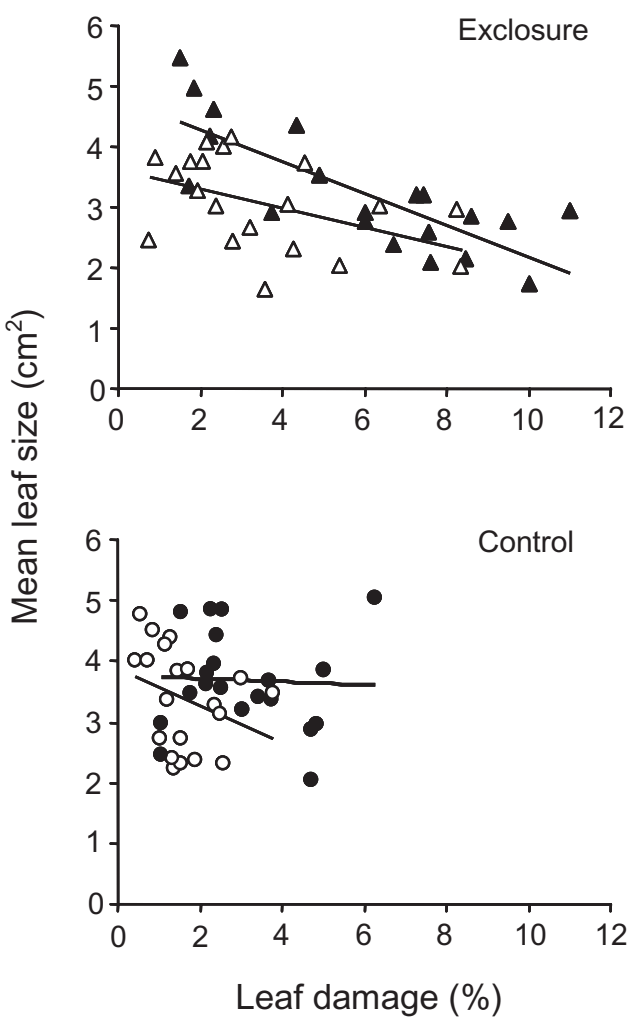

Fig. 2. Relationship between mean leaf size $\left(\mathrm{cm}^{2}\right)$ and leaf area damaged (\%) by chewing insects in Nothofagus pumilio saplings excluded from (upper panel) and exposed to (lower panel) bird access in dry (open symbols) and wet (closed symbols) forest sites. Regression lines were drawn by pooling data from two study years $(n=20)$. Least-square regressions were significant for caged (dry: $r^{2}=0.248, P=0.026$; wet: $\left.r^{2}=0.673, P<0.0001\right)$ but not control trees (dry: $r^{2}=0.131$, $P=0.12$; wet: $\left.r^{2}=0.013, P=0.64\right)$. Regression slopes for caged trees were not statistically different $(P=0.23)$.

The log response ratio $(L)$ allowed us to compare the effect magnitude of bird predation for different plant response variables. Excluding birds had an overall stronger effect on leaf damage than on mean 


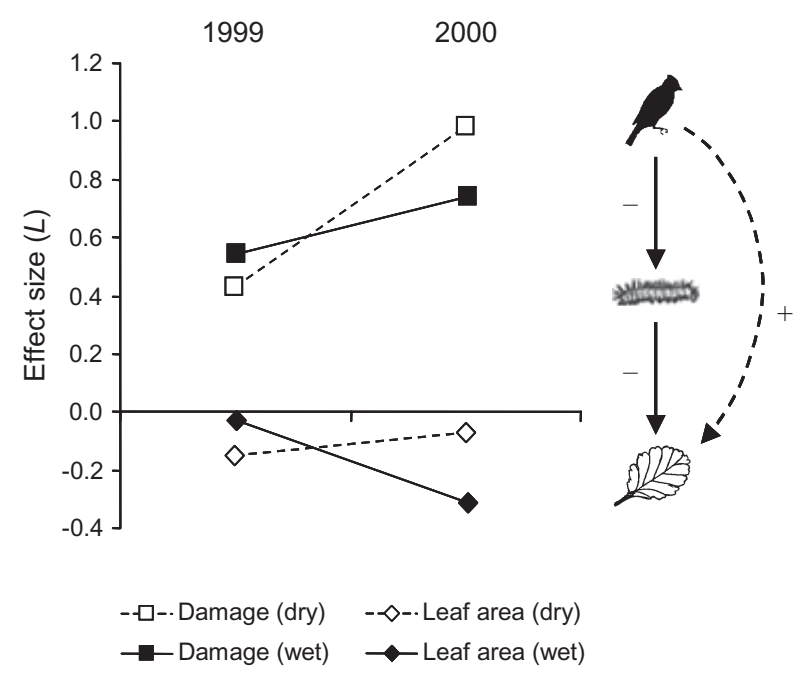

Fig. 3. The magnitude of bird exclusion effects on leafchewer damage (squares) and mean leaf size (diamonds) of Nothofagus pumilio saplings in dry and wet forest sites. Effect sizes were estimated using the $\log$ response ratio, $L=\ln \left(X_{\mathrm{E}} /\right.$ $\left.X_{\mathrm{C}}\right)$. Positive values indicate that bird exclusion increased leaf damage, whereas negative values indicate that exclosures reduced mean leaf size (including both insect damaged and intact leaves). The diagram shows the direct (solid arrows) and indirect (dashed arrow) effects involved in the trophic cascade; birds were assumed to decrease either the abundance or activity of leaf-chewing insects.

leaf size of saplings in both study years (Fig. 3). The effect size for both response variables increased in 2000 , although changes in mean leaf size remained comparatively small. Indeed, in 2000, enhanced bird predation effects on sapling leaf size were only apparent in the wet forest (Fig. 3).

\section{DISCUSSION}

Our experiment was originally designed to test for indirect effects of insectivorous birds on saplings. Unexpectedly, from spring 1998 through summer 2000 , the study area was affected by a severe drought, allowing us to assess the prevalence of top-down forces under the influence of an extreme climatic episode. We found that birds controlled folivory in dry and wet $N$. pumilio forests during both study seasons. However, the magnitude and relative importance of predation effects increased in 2000, as folivory rates also increased above baseline levels. Thus, after the drought, birds not only reduced the extent of leaf damage, but also benefited saplings through an increase in average leaf area. These results indicate that bird-initiated trophic cascades might protect saplings from insect damage even during years with abnormally high herbivory rates. Furthermore, this study adds to the growing view that large-scale climatic events (e.g. ENSO) might influence the strength of trophic interactions in terrestrial habitats (Jaksic 2001; Meserve et al. 2003; Preisser \& Strong 2004; Spiller \& Schoener 2008).

Bird exclusion increased folivory rates on tree saplings at two forest sites differing widely in annual precipitation and primary productivity (Mazía et al. 2004). Cages had a negligible impact on microclimate; therefore, we assumed that the greater leaf damage experienced by caged trees was due to the exclusion of bird predators (Marquis \& Whelan 1994; Sipura 1999; Van Bael et al. 2003). Simple food-chain models predict an increase in the strength of top-down forces along productivity gradients (Oksanen et al. 1981; Leibold 1989). In our case, folivory was higher on wet than on dry forest trees (Table 1, Fig. 1). Nevertheless, we did not find significant cage $\times$ site interactions that might suggest a between-site change in the magnitude of indirect effects as measured by plant damage. Bird population densities often track gradients in forest productivity and insect abundance (Seagle \& Sturtevant 2005; González-Gómez et al. 2006; Vergara \& Schlatter 2006), which could conceivably homogenize the relative strength of insectivory across sites. Overall, and based on $\eta^{2}$ values within ANOva (Table 2), bird predation was clearly as important as the forest habitat in determining folivory rates on $N$. pumilio saplings, and its relative importance increased in 2000 after the drought.

Baseline data for adult trees showed that background folivory during 2000 was higher than normal, especially in wet forest stands (Fig. 1). Although sapling damage also increased over the experiment, the average 1999-2000 change was twice as large for caged plants as for control ones (114 vs. 49\%, respectively; Table 1). This pattern suggests that top-down control from insectivorous birds protected saplings by preventing a sudden peak in folivory rates (see Fig. 1). Large-scale increases in forest herbivory associated with unusually hot/dry weather conditions are well known (Mattson \& Haack 1987; Schowalter \& Lowman 1999; Rouault et al. 2006). In the northern Patagonian Andes, La Niña events like that of 19992000 correspond with extremely dry winter-spring seasons coupled with very hot springs (Veblen \& Kitzberger 2002). Such abiotic conditions have been found to positively affect insect demography through enhanced winter survival and reproductive output in spring (Bale et al. 2002), leading to greater canopy defoliation in the ensuing summer (e.g. Rouault et al. 2006). Drought-induced stress has also been proposed to render trees more susceptible to insect attack, although evidence for leaf chewers is ambiguous (Koricheva et al. 1998).

Unfortunately, we were unable to collect bird abundance data to determine whether local populations varied in response to extreme drought conditions. 
However, field reports from southern Nothofagus forests show a decline in abundance of foliage-gleaning birds between 1999 and 2000 (Vergara \& Schlatter 2006). Birds are known to migrate during periods of food shortage, and might also reduce their foraging activity under abiotically stressful conditions created by low rainfall (Jaksic 2001; Jones et al. 2003). If this was the case, then folivorous insects might have also benefited from a transient reduction in total predation pressure during spring through early summer 19992000. Besides any presumed change in bird abundance, data indicate that by late summer 2000 insectivorous birds were capable of exerting a strong control over the amount of folivory on tree saplings (Table 1, Fig. 3). This is consistent with the notion that vertebrate predators might remain a significant top-down force over a wide range of insect prey densities (Parry et al. 1997; Dwyer et al. 2004; see also Sinclair \& Krebs 2002).

Recent meta-analyses of predator exclusion experiments suggest that the observed strength of trophic cascades depends on the plant response variable (Schmitz et al. 2000; Halaj \& Wise 2001). Top-down indirect effects appear to be stronger when measured as changes in plant damage rather than as changes in plant growth. Our results confirm such a pattern. Bird exclusion effects on sapling leaf size, when present, were smaller in magnitude and less consistent between sites than those on leaf damage rates (Fig. 3). In fact, during 1999, folivory was generally low and therefore indirect effects of bird predation on average leaf size were weak and statistically undetectable. This suggests that endemic folivory levels (Fig. 1) might not substantially affect leaf area in these forests, whereas elevated folivory rates during 2000 influenced the actual leaf size in saplings not accessible by birds (Fig. 2; see also Marquis \& Whelan 1994). Although we studied a simple (species) trophic cascade, our experiment suggests an attenuation of top-down effects at the plant level (Shurin et al. 2002; Gruner 2004). Birds were more effective at protecting trees from insect folivory than at facilitating leaf area growth (Fig. 3).

That plant growth components might not respond to predator indirect effects as much as insect damage does is not surprising given that plants possess various mechanisms to tolerate herbivory (Haukioja \& Koricheva 2000). In particular, deciduous woody plants might compensate for leaf area losses by expanding new leaves, a mechanism that depends on the number of pre-formed buds as well as on currentseason conditions (Kozlowski et al. 1991). Together with premature abscission and the continued expansion of damaged leaves, newly flushed leaves might dilute the actual impact of herbivores on mean leaf size (Schowalter \& Lowman 1999). The leaf size reduction found in heavily damaged (caged) saplings in 2000

(C) 2009 The Authors

Journal compilation (C) 2009 Ecological Society of Australia denoted a lack of compensation during the second study year. At this stage, after two drought years, all study trees showed signs of stress as their mean leaf size decreased from 1999 to 2000, irrespective of treatment and site (Table 1). Thus, in the absence of bird predators saplings faced a double-stress situation, whereby prior drought would have reduced their ability to buffer the impact of elevated folivory. Consequently, after 2 years of treatment, bird exclusion gave way to a significant decrease in average leaf size. These patterns concur with other studies suggesting that trophic cascades might be conditional on the timing and extent of rainfall (Dawes-Gromadzki 2002; Ovadia \& Schmitz 2004).

The magnitude of bird exclusion effects on leaf area size (2000) was greater on wet forest trees (Fig. 3). This trend could reflect the fact that both the frequency of damage and the amount of leaf area removed by insects were higher in wet than in dry forest (Table 1). In addition, we suggest that dry forest saplings could be capable of compensating for the leaf area lost to herbivores by flushing new leaves through the growing season (Waring \& Schlesinger 1985; Kozlowski et al. 1991). This hypothesis is consistent with data from a greenhouse experiment in which young $N$. pumilio saplings from dry and wet forest sites showed differential abilities to recover from defoliation (Garibaldi et al. unpub. data 2008). Whereas dry forest saplings had a staggered pattern of leaf expansion that helped them to replace leaf area losses, wet forest plants showed just one leaf flushing event. Furthermore, the sparser canopy cover of dry forest sites (Veblen et al. 1996) would provide saplings with better light conditions for protracted leaf cohorts. By contrast, deep-shade conditions in more productive, wet forests might limit the ability of understorey saplings to compensate for insect herbivory.

Global change scenarios predict increased frequencies of climatic anomalies like ENSO events (Holmgren et al. 2001). Therefore, understanding how extreme abiotic changes might alter food-web interactions has become a primary concern (Jaksic 2001; Schmitz et al. 2003). Extreme events might weaken top-down controls when they act destructively (e.g. hurricanes), drastically reducing top predator abundance (Spiller \& Schoener 2008). Alternatively, climatic episodes, such as high-rainfall years might enhance top-down forces when they directly benefit predators (Preisser \& Strong 2004) or create resource flushes transmitted from the bottom up to higher trophic levels, inducing lagged predator responses (Polis et al. 1997; Meserve et al. 2003). Our study illustrates how the intensity of a tree-based trophic cascade increased under low rainfall conditions of $\mathrm{La}$ Niña, apparently because prevailing abiotic conditions enhanced forest insect performance. This finding suggests that the functional role of certain predators

doi:10.1111/j.1442-9993.2009.01933.x 
might become most evident during climatically exceptional years.

\section{ACKNOWLEDGEMENTS}

We thank K. Heinneman and N. Tercero Buccardo for field help. The Administración de Parques Nacionales granted us permission to work at Nahuel Huapi National Park. The study was funded by Grants from Agencia Nacional de Promoción Científica y Tecnológica (BID 802/OC-AR PICT 2268 and BID 1728/OC-AR PICTR 331/1), Universidad de Buenos Aires (G-407) and Fundación Antorchas.

\section{REFERENCES}

Bale J. S., Masters G. J., Hodkinson I. D. et al. (2002) Herbivory in global climate Change research: direct effects of rising temperatures on insect herbivores. Glob. Change Biol. 8, $1-16$.

Barros V., Cordón V., Moyano C., Méndez R., Forquera J. \& Pizzio O. (1983) Cartas de precipitación de la zona oeste de las provincias de Rio Negro y Neuquén. Internal Report, Facultad de Ciencias Agrarias, Universidad Nacional del Comahue, Neuquén.

Bauerle P., Rutherford P. \& Lanfranco D. (1997) Defoliadores de roble (Nothofagus obliqua), raulí ( $N$. alpina), coihue ( $N$. dombeyi) y lenga (N. pumilio). Bosque 18, 97-107.

Bernardo J. (1998) The logic, value, and necessity of grounding experiments in reality: an essential link in the inferential chain back to nature. In: Experimental Ecology: Issues and Perspectivas (eds W. J. Resetarits \& J. Bernardo) pp. 370-93. Oxford University Press, Oxford.

Chase J. M. (1996) Abiotic controls of trophic cascades in a simple grassland food-chain. Oikos 77, 495-506.

Crawley M. J. (1993) GLIM for Ecologists. Blackwell Scientific, Oxford.

Dawes-Gromadzki T. Z. (2002) Trophic trickles rather than cascades: conditional top-down and bottom-up dynamics in an Australian chenopod shrubland. Aust. Ecol. 27, 490-508.

Deferrari G., Camilión C., Martínez Pastur G. \& Peri P. L. (2001) Changes in Nothofagus pumilio forest biodiversity during the forest management cycle. 2. Birds. Biodiv. Conserv. 10, 2093-108.

Dwyer G., Dushoff J. \& Harrell Yee S. (2004) The combined effects of pathogens and predators on insect outbreaks. Nature 430, 341-5.

Forkner R. E. \& Hunter M. D. (2000) What goes up must come down? Nutrient addition and predation pressure on oak herbivores. Ecology 81, 1588-600.

Fraser L. H. \& Grime J. P. (1998) Top-down controls and its effects on the biomass and composition of three grasses at high and low soil fertility in outdoor microcosms. Oecologia 113, 239-46.

Gentili M. \& Gentili P. (1988) Lista comentada de los insectos asociados a las especies sudamericanas del género Nothofagus. Monogr. Acad. Nac. Cs. Ex. Fis. y Nat. 4, 85-106.

González-Gómez P. L., Estades C. F. \& Simonetti J. A. (2006) Strenghtened insectivory in a temperate forest fragment. Oecologia 148, 137-43.
Gruner D. (2004) Attenuation of top-down and bottom-up forces in a complex terrestrial community. Ecology 85, 301022.

Hacker S. D. \& Bertness M. D. (1995) A herbivore paradox: why salt marsh aphids live on poor-quality plants. Am. Nat. 145, 192-210.

Hairston N. G., Smith F. E. \& Slobodkin L. B. (1960) Community structure, population control, and competition. Am. Nat. 94, 421-5.

Halaj J. \& Wise D. H. (2001) Terrestrial trophic cascades: how much do they trickle?. Am. Nat. 157, 262-81.

Haukioja E. \& Koricheva J. (2000) Tolerance to herbivory in woody versus herbaceous plants. Evol. Ecol. 14, 551-62.

Hedges L. V., Gurevitch J. \& Curtis P. S. (1999) The metaanalysis of response ratios in experimental ecology. Ecology 80, 1150-6.

Holmes R. T., Schultz J. C. \& Nothnagle P. (1979) Bird predation on forest insects: an exclosure experiment. Science 206, 462-3.

Holmgren M., Scheffer M., Ezcurra E., Gutiérrez J. R. \& Mohren G. M. J. (2001) El Niño effects on the dynamics of terrestrial ecosystems. Trends Ecol. Evol. 16, 89-94.

Hunter M. D. \& Price P. W. (1992) Playing chutes and ladders: heterogeneity and the relative roles of bottom-up and topdown forces in natural communities. Ecology 73, 724-32.

Jaksic F. M. (2001) Ecological effects of El Niño in terrestrial ecosystems of western South America. Ecography 24, 24150.

Jones J., Doran P. J. \& Holmes R. T. (2003) Climate and food synchronize regional forest bird abundances. Ecology 84, 3024-32.

Koricheva J., Larsson S. \& Haukioja E. (1998) Insect performance on experimentally stressed woody plants: a meta-analysis. Annu. Rev. Entomol. 43, 195-216.

Kozlowski T., Kramer P. \& Pallardy S. (1991) The Physiological Ecology of Woody Plants. Academic Press, New York.

Laska M. S. \& Wootton J. T. (1998) Theoretical concepts and empirical approaches to measuring interaction strength. Ecology 79, 461-76.

Leibold M. A. (1989) Resource edibility and the effects of predators and productivity on the outcome of trophic interactions. Am. Nat. 134, 922-49.

Letourneau D. K., Dyer L. A. \& Vega G. (2004) Indirect effects of a top predator on a rain forest understory plant community. Ecology 85, 2144-52.

Low C. \& Connor E. F. (2003) Birds have no impact on folivorous insect guilds on a montane willow. Oikos 103, 579-89.

McQuillan P. B. (1993) Nothofagus (Fagaceae) and its invertebrate fauna - an overview and preliminary synthesis. Biol. F. Linn. Soc. Lond. 49, 317-54.

Marquis R. J. \& Whelan C. J. (1994) Insectivorous birds increase growth of white oak through consumption of leaf-chewing insects. Ecology 75, 2007-14.

Mattson W. J. \& Haack R. A. (1987) The role of drought in outbreaks of plant-eating insects. BioScience 37, 110-18.

Mazía C. N., Kitzberger T. \& Chaneton E. J. (2004) Interannual changes in folivory and bird insectivory along a natural productivity gradient in northern Patagonian forests. Ecography 27, 29-40.

Meserve P. L., Kelt D. A., Milstead W. B. \& Gutierrez J. R. (2003) Thirteen years of shifting top-down and bottom-up control. BioScience 53, 633-46.

Mooney K. A. (2007) Tritrophic effects of birds and ants on a canopy food web, tree growth, and phytochemistry. Ecology 88, 2005-14. 
Murakami M. \& Nakano S. (2000) Species-specific bird functions in a canopy food-web. Proc. R. Soc. Lond. B. Biol. Sci. 267, 1597-601.

Oksanen L., Fretwell S. D., Arruda J. \& Niemela P. (1981) Exploitation ecosystems in gradients of primary productivity. Am. Nat. 118, 240-61.

Osenberg C.W., Sarnelle O. \& Cooper S. D. (1997) Effect size in ecological experiments: the application of biological models in meta-analysis. Am. Nat. 150, 798-812.

Ovadia O. \& Schmitz O. J. (2004) Weather variation and trophic interaction strength: sorting the signal from the noise. Oecologia 140, 398-406.

Pace M. L., Cole J. J., Carpenter S. R. \& Kitchell J. K. (1999) Trophic cascades revealed in diverse ecosystems. Trends Ecol. Evol. 14, 483-8.

Parry D., Spence J. R. \& Volney W. J. A. (1997) Responses of natural enemies to experimentally increased populations of the forest tent caterpillar, Malacosoma disstria. Ecol. Entomol. 22, 97-108.

Petraitis P. S. (1998) How can we compare the importance of ecological processes if we never ask, compared to what? In Experimental Ecology: Issues and Perspectivas (eds W. J. Resetarits \& J. Bernardo) pp. 183-201. Oxford University Press, Oxford.

Polis G. A. (1999) Why are parts of the world green? Multiple factors control productivity and the distribution of biomass. Oikos 86, 3-15.

Polis G. A., Hurd S. D., Jackson C. T. \& Sanchez Piñero F. (1997) El Niño effects on the dynamics and control of an island ecosystem in the Gulf of California. Ecology 78, 188497.

Preisser E. L. \& Strong D. (2004) Climate affects predator control of an herbivore outbreak. Am. Nat. 163, 754-62.

Ritchie M. E. (2000) Nitrogen limitation and trophic versus abiotic influences on insect herbivores in a temperate grassland. Ecology 81, 1601-12.

Rosenzweig M. L. (1973) Exploitation in three trophic levels. Am. Nat. 107, 275-94.

Rouault G., Candau J. N., Lieutier F., Nageleisen L. M., Martin J. C. \& Warzée N. (2006) Effects of drought and heat on forest insect populations in relation to the 2003 drought in Western Europe. Ann. For. Sci. 63, 613-24.

Schmitz O. J., Hambäck P. A. \& Beckerman A. P. (2000) Trophic cascades in terrestrial systems: a review of the effects of carnivore removals on plants. Am. Nat. 155, 141-53.

Schmitz O. J., Post E., Burns C. E. \& Johnston K. M. (2003) Ecosystem responses to global climate change: moving beyond color mapping. BioScience 53, 1199-204.

Schowalter T. D. \& Lowman M. D. (1999) Forest herbivory insects. In: Ecosystems of Disturbed Ground (ed. L. R. Walker) pp. 177-96. Elsevier, Amsterdam.
Seagle S. W. \& Sturtevant B. R. (2005) Forest productivity predicts invertebrate biomass and Ovenbird (Seiurus aurocapillus) reproduction in Appalachian landscapes. Ecology 86, 1531-9.

Shure D. J., Mooreside P. D. \& Ogle S. M. (1998) Rainfall effects on plant-herbivore processes in an upland oak forest. Ecology 79, 604-17.

Shurin J. B., Borer E. T., Seabloom E. W. et al. (2002) A crossecosystem comparison of the strenght of trophic cascades. Ecol. Lett. 5, 785-91.

Sinclair A. R. E. \& Krebs C. J. (2002) Complex numerical responses to top-down and bottom-up processes in vertebrate populations. Philos. Trans. R. Soc. Lond. B. Biol. Sci. 1221-31.

Sipura M. (1999) Tritrophic interactions: willows, herbivorous insects and insectivorous birds. Oecologia 121, 537-45.

Spiller D. A. \& Schoener T.W. (2008) Climatic control of trophic interaction strength: the effect of lizards on spiders. Oecologia 154, 763-71.

StatSoft Inc. (1999) STATISTICA for Windows. Computer Program Manual. StatSoft, Tulsa, OK.

Stiling P. \& Rossi A. M. (1997) Experimenrtal manipulation of top-down and bottom-up factors in a tri-trophic system. Ecology 78, 1602-6.

Strong A. M., Sherry T. W. \& Holmes R. T. (2000) Bird predation on herbivorous insects: indirect effects on sugar maple saplings. Oecologia 125, 370-9.

Suárez M. L., Ghermandi L. \& Kitzberger T. (2004) Factors predisposing episodic drought-induced tree mortality in Nothofagus - site, climatic sensitivity and growth trends. F. Ecol. 92, 954-66.

Turchin P., Taylor A. D. \& Reeve J. D. (1999) Dynamical role of predators in population cycles of a forest insect: an experimental test. Science 285, 1068-70.

Van Bael S., Brawn J. D. \& Robinson S. K. (2003) Birds defend trees from herbivores in a Neotropical forest canopy. Proc. Natl. Acad. Sci. U.S.A. 100, 8304-7.

Veblen T. T. \& Kitzberger T. (2002) Inter-hemispheric comparison of fire history: the Colorado Front Range, U.S.A., and the northern Patagonian Andes, Argentina. Plant Ecol. 163, 187-207.

Veblen T. T., Donoso C., Kitzberger T. \& Rebertus A. (1996) Ecology of southern Chilean and Argentinean Nothofagus forest. In: The Ecology and Biogeography of Nothofagus Forests (eds T. T. Veblen, R. Hill \& J. Read) pp. 293-353. Yale University Press, New Haven.

Vergara P. M. \& Schlatter R. P. (2006) Aggregate retention in two Tierra del Fuego Nothofagus forests: Short-term effects on bird abundance. For. Ecol. Manage. 225, 213-24.

Waring R. H. \& Schlesinger W. H. (1985) Forest Ecosystems: Concepts and Management. Academic Press, New York. 